\title{
Renal Pelvis and Ureter Cancer Pathologic Regional Lymph Nodes TNM Finding v8
}

National Cancer Institute

\section{Source}

National Cancer Institute. Renal Pelvis and Ureter Cancer Pathologic Regional Lymph

Nodes TNM Finding v8. NCI Thesaurus. Code C140348.

A pathologic finding about one or more characteristics of renal pelvis and ureter cancer, following the rules of the TNM AJCC v8 classification system as they pertain to staging of regional lymph nodes. 